\title{
The Academic Community Capacity of The Universitas Negeri Semarang (UNNES) In Dealing With Natural Disasters
}

\author{
Edi Kurniawan $^{1}$, Sriyanto ${ }^{2}$, Mohammad Syifauddin ${ }^{3}$ \\ \{edikurniawan@mail.unnes.ac.id ${ }^{1}$, sriyantogeo@mail.unnes.ac.id ${ }^{2}$, syifauddin31@ gmail.com ${ }^{3}$ \} \\ 1,2,3 Universitas Negeri Semarang, Indonesia
}

\begin{abstract}
As one of the educational institutions, Universitas Negeri Semarang(UNNES) has great urgency in constructing the capacity of its academic community in dealing with disasters. Universitas Negeri Semarang, which is a home of knowledge for students from various elements, and at the same time as a conservation university, also has a high susceptibility toward disasters due to its geographic conditions and the existence of tens of thousands of its academic community. This study was aimed to determine the perception and the capacity of the UNNES academic community in dealing with disasters, so that it became a reference framework for the university in developing policies related to the disaster risk management in the campus environment. This research was conducted by a qualitative approach with data collection methods in the form of observation, interviews, questionnaires, and documentation, as well as data analysis techniques used was interaction methods. According to the research conducted, it was obtained information that the campus communities had a positive perception of disaster mitigation efforts. However, those were not accommodated by the policy of the university to increase the campus communities' capacity in dealing with disasters, both in the form of disaster mitigation education programs or the support of adequate facilities. Therefore, the efforts to increase the capacity of campus communities in dealing with disasters must be realized by the university immediately so that they could set up the campus communities who were resilient to disasters.
\end{abstract}

Keywords: Capacity, Disaster, Mitigation, Perception, Universitas Negeri Semarang.

\section{Introduction}

Behind its natural beauty and wealth, Indonesia holds the potential for a very large disaster threat that can damage the livelihoods of its citizens. This is influenced by geographical, geological, climatic, and ecological location factors of the Indonesian region, along with socio-economic factors of the Indonesian people [1][2]. The disaster that occurred in Indonesia has caused various negative impacts, they were fatalities and material damages that were not small. Reported by Kompas, the amount of damages due to the earthquake in Lombok, Nusa Tenggara Barat in 2018 was 10.15 Trillion Rupiahs [3]. Then, the damages amount due to the earthquake and tsunami in Palu-Donggala in 2018 reached 18.48 Trillion Rupiah [4]. The number of disasters in Indonesia also showed a high number, that was in 2018-2019, the number of disasters recorded by BNPB reached 5,271 disasters [5]. In fact, in 2019, from January to March,the BNPB noted that there were at least 1,107 disasters that occurred in Indonesia [6]. 
These conditions indicated that there were still a weak capacity of the Indonesian people in dealing with disasters [7]. This problem was caused by several factors, including the inability of the community both related to the technical, cost, and time unpreparedness, the lack of knowledge about disaster preparedness, and the weak of social and cultural capital that causes social, economic, and cultural susceptibility [8]. Another factor that is being a problem is the paradigm shifting in disaster handling, start from being a reactive, passive and centralistic and then being an oriented towards the preventive attempts, disaster risk reduction (mitigation) and community capacity strengthening. This condition was a revolutionary effort of the Indonesian people, in contrast, its reality was still not able to answer these idealism which were marked by the unavailable derivation from the shifting into the real level through various regulations and disaster prevention programs, including theunpreparedness of the community to adapt and actively participate in these progressive efforts [9].

According to the above description, the community capacity strengthening in dealing with disasters was a certainty, both for the foundation of the paradigmatic shifting that was happening and the technical objectives [9]. This was because the capacity of the community in implementing the disaster prevention was an important parameter and a success determinant of a disaster risk reduction program [10]. It is also inseparable from the nature of disaster which is a causal relationship between threats, susceptibility and capacities. The risk will be directly proportional to susceptibility and threat, and inversely proportional to mitigation capacity. Thus, disaster risk could be minimized by increasing the mitigation capacity (the endurance and the preparedness) [11]. Therefore, the construction of the community capacity is a crucial effort that has a huge urgency. This urgency is motivated by the reality that the government will not be able to do a disaster risk reduction without actively involving the community. Community involvement in the disaster risk reduction efforts was absolutely required because the community is both the subject and object of the disaster risk reduction efforts [12].

This fact has been proven by the study of Kusumawardhani, Tahajuddin, and Wardiat (2014) [9], Jaswadi, Rijanta, and Hadi (2012) [11], Saluki (2015) [13], Wahyuni, Fatimah, and Azmeri (2015) [14], and Sitorus, (2018) [15]. From these studies, it was concluded that community capacity had a great urgency in disaster mitigation efforts. This was because the threat will become a disaster if the community is susceptible or has a lower capacity than the emergency level or even becomes one of the sources of the threat. Then, the existence of disaster risk is something that often becomes a problem outside of human intention so that the effective step to deal with it is not by blocking the disaster, but rather increasing the capacity of the community to be stronger and ready to face the disaster.

The efforts to increase the community capacity must be intensified through various institutions and media, one of which is through the formal education. One of the educational institutions that has great urgency in constructing the capacity of its academic community is Universitas Negeri Semarang (UNNES). As a higher education institution that is a home of knowledge for various elements' students, and at the same time as a conservation university, UNNES has an important role in increasing the capacity of its academic community in dealing with disasters. This was motivated by the fact that disaster is a natural will that cannot be avoided by the community, so they must be able to prepare themselves by constructing the capacity in the disaster prevention to reduce the potential disasters risk [16]. Therefore it was necessary to conduct a research to determine the capacity of the academic community in dealing with disasters, so that it could become a reference for the university in developing policies related to disaster risk management in the campus environment. 


\section{Methodology}

The study was conducted by a qualitative approachand was conducted at the Faculty of Social Sciences, Universitas Negeri Semarang (UNNES), by taking a case study in C7 Building, Faculty of Social Sciences, UNNES. The consideration in choosing it as the focus of the study was because it was one of the buildings in UNNES which is often used to hold events on campus, both by the Faculty of Social Sciences and by other faculties at UNNES, so it is a building that is often visited by community campus of the UNNES. That way, the C7 building was classified for having a high susceptibility towards the disaster, especially earthquake and fire disasters that can occur at any time without being predictable. Then, its choice would also provide a broader picture of the data which was to be examined because the building's users consist of campus communities from various faculties.

The sample selection was conducted purposively, by considering the campus communities who were users of C7 Building. The data sources consisted of primary and secondary data. Primary data were obtained through observation, interviews, documentation and questionnaires, while secondary data were obtained from the related agencies data such as universities, BNPB, BPS data, previous scientific journals, and various social media. The data analysis method in this study was carried out by qualitative analysis which was carried out data interactions according to Miles and Huberman (1994). The data obtained by the report was in the form of qualitative data and then processed with an interactive model. The steps of the interactive model included four activities,they were: data collection, data reduction, presentation of data (data display), and data verification (conclusing drawing) [17].

\section{Result and Discussion}

\subsection{Campus Communities' Perceptions towards Disasters}

According to the data obtained, it showed that the majority of UNNES campus communities had positive perceptions related to disasters. The first important point related to campus communities' perceptions towards disaster was the campus communities paradigm which said that disaster was a serious threat that was having risks to threaten the resilience and the life of the community so that it had enormous urgency to be handled immediately. Campus communities realized that the disaster was a threat that must be overcome because of the potential to lose the communities' life and material. Campus communities knew that disaster mitigation effort was very important to do and was one of the crucial cases that must become a focus for various existing stakeholders immediately.

Natural disasters are phenomena that occur outsidethe human will. The community will not be able to eliminate the existence of disasters. The community is only able to minimize the risk of disasters that can threaten their survival. This was done by the community through disaster mitigation efforts to increase their capacity in dealing with disasters. This effort was a certainty for the community and should not be a discourse between communities. This has been understood in depth by the citizens of the UNNES campus that to protect themselves from the disaster's threat, the best step that can be taken was to conduct disaster mitigation efforts so it was to be able to increase the communities' capacity in dealing with disasters. They perceived that the disaster mitigation efforts became important to be realized immediately.

UNNES campus communities also understood that natural disasters could occur anywhere and at any time without the community knowing when they arrive. Natural disasters 
would be directly proportional to the magnitude of vulnerabilities and threats that exist in society. Society was a social creature that is mobile and dynamic so that they can move from one place to another. Therefore, the effort to implement the disaster mitigation education must be transformed in various areas; however it was not limited to the disasters-prone areas. The campus communities realized that disaster mitigation education was the need of each individual as well as individual need for other knowledge, for example the knowledge related to language, arithmetic, and other sciences.

However, there were still lots of campus communities who had a paradigm that disaster mitigation education was only necessary in areas that are prone to havea disaster. This paradigm must be immediately straightened because we will never know where we are when the disaster occurs. We will never be able to predict whether we will always be in a safe place from the threat of disaster, or at a certain time, there is a moment that forces us to move into an area that is not safe from the threat of disaster. Misperceptions and paradigm errors related to disaster still become a problem in the efforts of disaster mitigation education. Whereas, in fact, disaster mitigation education efforts are very important sinceitcanimprove the capacity of communities to adapt to the environment and the threat of disaster wherever they are.

\subsection{The Capacity of Campus Communities in Dealingwith Disasters}

Community capacity is the ability of the community to take action in order to reduce threats and potential losses caused by disasters. According to Nugraha, Nugraheni, and Kurniawan (2016), community capacity can be viewed from two aspects, they are individual capacity and institutional capacity. Individual capacity is influenced by knowledge, action plans, and local wisdoms. Whereas, the institutional capacity is influenced by leadership and programs, facilities, and information[2]. The concept of community capacity is shownin Figure 1 below.

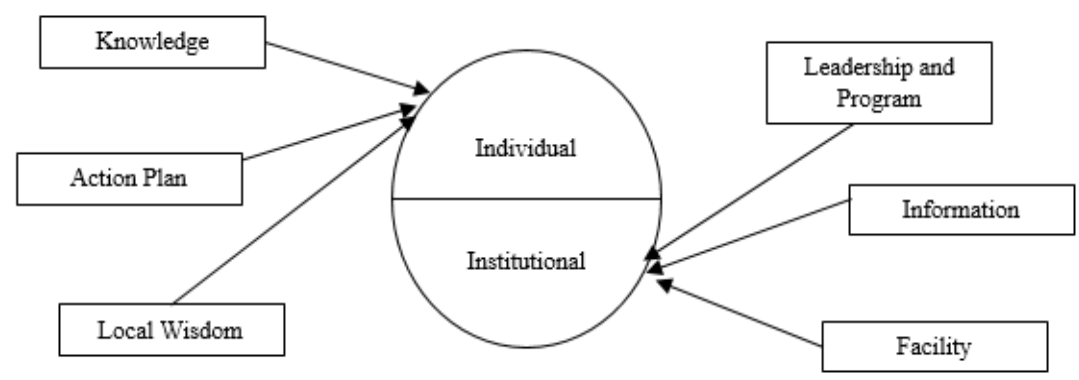

Figure 1. Indicators of Community Capacity

Source: Nugraha, Nugraheni dan Kurniawan (2016).

According to the theory from Nugraha, Nugraheni, and Kurniawan (2016), indicators of community capacity in facing disaster consist of:

a. Mitigation knowledge which includes general disaster knowledge, knowledge of selfrescue from disasters, having experiences in training/seminars/simulations on disaster preparedness, having experiences of natural disasters, knowledge about residence areas that are prone to disasters, family knowledge about disasters. 
b. Action plan which includes preparations for securing valuable things and preparation for self-rescue plans from disasters.

c. Local wisdom which includes perception and motivation.

d. Leadership and Programs which include government efforts to enhance disaster awareness, responsible parties in preparation of facing disasters, management approaches in coping with disasters, government efforts in early warning of disasters.

e. Information which include the role of the media in disaster preparedness and sources of information and media.

f. Facilities which include the availability of evacuation routes and the availability of early warning facilities [2].

Regarding knowledge about mitigation, $37.5 \%$ of respondents still hadpoor knowledge about disaster. This was indicated by the low level of knowledge about disasters in general, knowledge in identifying potential disasters, knowledge in identifying the symptoms of disasters, and knowledge about the causes of disasters. Then, $25 \%$ of respondents had very minimal experience related to the experience of participating in training programs, seminars, or simulations on disaster preparedness. From all respondents, $25 \%$ of respondents had never even participated in a disaster mitigation education program. Knowledge of the respondents can be seen through the diagram in Figure 2 and Figure 3 below.

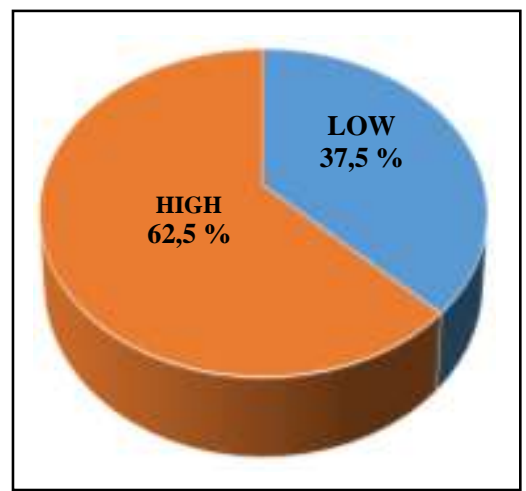

Figure 2. Level of respondent knowledge about disaster mitigation

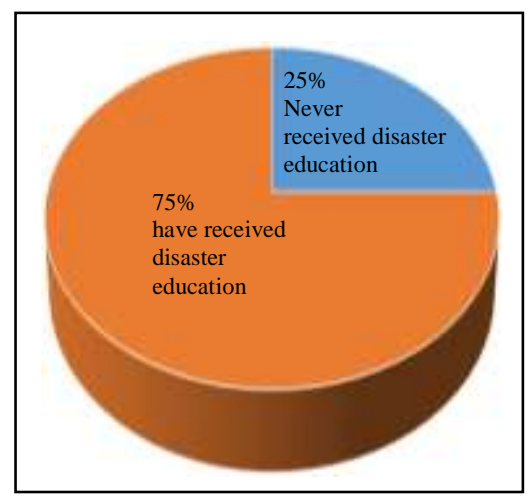

Figure 3. The experienc of respondent in received disaster education

For the aspect of the action plan, the respondent does not yet have good capacity in facing disasters. This was because they did not completely understand in detail how to protect or save themselves when a disaster occurs. They knew how to mitigate when a disaster occurs, but only in general aspects and not the detailed steps. For instance, in protecting themselves from earthquakes, how to escape from a room during an earthquake and fire, how to turn off a fire during a fire, and how to use the evacuation routes when a disaster occurs.

In the aspect of local wisdom, respondents did not show the local wisdom values so much in interpreting the phenomenon of disaster. Local wisdom includes the values of life and culture of the community which reinforce them to increase the community capacity. They had weak local wisdom values that they only made a very small contribution in strengthening their capacity. Local wisdom is very effective as a community spirit in responding to various kinds of disasters since the values of local wisdom can reduce vulnerability and also increase 
motivation and bring positive community perceptions. One of the tangible forms of local wisdom was shown by a number of respondents who put forward religious values in dealing with disasters. These values were manifested in the their perception that disaster is God's will as a reminder for human so that they must pray to God in order to be protected from the threats or risks of disaster.

In the aspect of leadership and program, it was shownthat the capacity of campus communities in facing disasters was still weak. This wasbecause the lack of campus efforts in reducing disaster risk, the lack of campus efforts in improving disaster awareness, the absence of people who are specifically responsible for preparing to deal with disaster, and the most crucial thing was the lack of programs from universities related to providing disaster education. So far, the disaster education program has only been done by the Student Activity Unit, KSR PMI UNNES and UKM KSG Social Adventure Club at around Faculty of Social Sciences. However, this program was not able to improve the capacity of campus communities to deal with disasters properly because the training program was held only once and there was still minimal participation of campus communities to participate in this activity. Another disaster mitigation education program was carried out in the Department of Geography Faculty of Social Sciences through classroom learning, training for cadres of Sekolah Berwawasan Lingkungan dan Bencana (SWALIBA) and several seminars on the theme of disaster. However, this program was only able to accommodate campus communities from the Department of Geography alone, and was not able to accommodate all campus community of UNNES.

The aspect of information also showed the weakness of campus communities in dealing with disasters. This was due to the role of the campus media that was still low in socializing disaster mitigation efforts. For the time being, there is no campus media which become a source of information and education media for campus communities related to disaster mitigation efforts. This is the duty for the campus to provide information with educational content about disasters, especially in the campus environment. So, it can improve the capacity of campus communities in dealing with disasters.

The aspect of facility is also an indicator of capacity in dealing with disasters. Regarding facilities, campus capacity in dealing with disasters was still weak as well. This wasbecause the lack of early warning facilities available in C7Building. C7 Building was not equipped with an early warning system. For instance, there were no fire alarm alerts. Then, C7 Building was not also equipped with adequate evacuation routes and the unavailability of adequate fire extinguisher (tube). C7 building design was also less friendly to disasters. For example, a narrow stair and a narrow door design and open inward will make the evacuation process is more difficult.

\section{Conclusion}

The majority of UNNES campus community have positive perceptions regarding disasters. Therefore, campus communities have a perception that disaster mitigation education is a necessity in order to improve their capacity in dealing with disasters. However, the positive perceptions of campus communities are not accommodated by the policy of the university to increase the capacity of campus communities in dealing with disasters, either in the form of disaster mitigation education programs or the support of adequate facilities so that there are still campus communities who have poor knowledge about disasters and action plan for dealing with disasters. There are still many campus communities who have never 
participated in a disaster mitigation education program at all and there are still no campus efforts to make a media movement in promoting disaster mitigation education. Therefore, efforts to improve the capacity of campus communities in dealing with disasters must be realized by the university so that they can build campus communities who are resilient to any disasters.

\subsection{Acknowledgments}

This project is financially supported by the Faculty of Social Sciences Universitas Negeri Semarang.

\section{References}

[1] Priyono, Kuswaji Dwi and Fitria Endah Lestari: Peningkatan Kapasitas Masyarakat dalam Menghadapi Bencana Erupsi Gunungapi Kelud Melalui Pariwisata Bencana (Disaster Tourism) di Kecamatan Nglegok Kabupaten Blitar. Proceeding of The $6^{\text {th }}$ University Research Colloquium 2017 Universitas Muhammadiyah Magelang. Pp. 93-103 (2017).

[2] Nugraha, Jaka, Fitri N, and Irwan NK: Model Kapasitas Masyarakat dalam Menghadapi Bencana Menggunakan Analisis Regresi Logistik Ordinal. Jurnal Eksakta. Vol. 16, no. 1, pp. 17-26 (2016).

[3] Prabowo, Dani: Terus Bertambah, Kerugian Akibat Gempa Lombok Tembus Rp 10,15 T. https://properti.kompas.com/read/2018/09/10/150619321/terus-bertambah-kerugianakibat-gempa-lombok-tembus-rp-1015-t (2018).

[4] Rachman, DA: BNPB Catat Kerugian Dampak Bencana Sulteng Mencapai 18,48 Triliun. https://nasional.kompas.com/read/2018/10/28/19120431/bnpb-catat-kerugiandampak-bencana-sulteng-menjadi-rp-1848-triliun (2018).

[5] BNPB: Bencana Alam di Indonesia Tahun 2018 s/d 2019. http://bnpb.cloud/dibi/tabel1a (2019).

[6] Safitri, Eva: BNPB Catat Ada 1.107 Bencana di Indonesia SejakJanuari-Maret 2019. https://news.detik.com/berita/d-4489293/bnpb-catat-ada-1107-bencana-di-indonesiasejak-januari-maret-2019 (2019)

[7] Prihananto, F.G and Lutfi Muta'ali: Kapasitas Masyarakat dalam Upaya Pengurangan Risiko Bencana Berbasis Komunitas di Desa Wonolelo Bantul. Jurnal Bumi Indonesia. Vol. 2, no. 4, pp. 1-9 (2013).

[8] Mohammad, Nezar Ely, and Erni S, and Heri T: Kapasitas Masyarakat Terhadap Ancaman Bencana Tanah Longsor di Kecamatan Banyubiru Kabupaten Semarang Tahun 2017. Jurnal Edu Geography. Vol. 6, no. 1, pp. 44-52 (2018).

[9] Kusumawardhani, DTP, Ujud T, and Dede W: Model Penguatan kapasitas Masyarakat dalam Pengurangan Risiko Bencana Alam di Indonesia. Proceeding of Pemaparan Hasil Penelitian Pusat Penelitian Geoteknologi LIPI. pp. 22-36 (2014).

[10] Rahman, Amni Zarkasyi: Kapasitas Daerah Banjarnegara dalam Penanggulangan Bencana Alam Tanah Longsor. Jurnal Ilmu Sosial. Vol. 16, no. 1, pp. 1-8 (2017).

[11] Jaswadi, R Rijanta, and Pramono H: Tingkat Kerentanan dan Kapasitas Masyarakat dalam Menghadapi Risiko Banjir di Kecamatan Pasarkliwon Kota Surakarta. Jurnal Majalah geografi Indonesia. Vol. 26, no. 1, pp. 119-148 (2012). 
[12] Susilowati, Fitri and Lilik Siswanta: Peningkatan Kapasitas Masyarakat dalam Menghadapi Risiko Bencana Berbasis Gender. Jurnal Semar. Vol. 5, no. 1, pp. 41-49 (2016)

[13] Saluki: Peningkatan Kapasitas Kelompok Masyarakat Siaga Bencana dalam Mengurangi Risiko Bencana Gunung Tangkubanperahu Kabupaten Bandung Barat. Jurnal Ilmiah Pekerjaan Sosial. Vol. 14, no. 2, pp. 161-173 (2015).

[14] Wahyuni, Eldina F, and Azmeri: Analisis Tingkat Kerentanan dan Kapasitas Masyarakat Terhadap Bencana Banjir Bandang Kecamatan celala Kabupaten Aceh Tengah. Jurnal Ilmu Kebencanaan. Vol. 2, no. 3, pp. 33-40 (2015).

[15] Sitorus, Purnama Betty Rosalyna: Budaya Kerentanan dan Kapasitas Masyarakat Kepulauan Mentawai Menghadapi Bencana gempa Bumi dan Tsunami. Jurnal Vokasi Indonesia. Vol. 2, no. 2, pp. 25-32 (2018).

[16] Buchari Ahmad, Meilanny BS, and Nina M: Pengembangan Kapasitas Kelembagaan Desa Tangguh Bencana di Kabupaten Garut (Studi Kasus di Desa Persawahan Kecamatan Tarogong Kaler. Jurnal Analisis dan Kebijakan Publik. Vol. 3, no. 1, pp. 4962 (2017).

[17] Huberman, A. Michael: Qualitative Data Analysis Thousand Oaks: Sage (1994). 